\title{
PERSPEKTIF TEORI STRUKTURAL FUNGSIONALISME TENTANG KETAHANANAN SISTEM PENDIDIKAN PESANTREN
}

\author{
Samsul Bahri \\ Fakultas Tarbiyah dan Keguruan IAIN Kendari \\ Jl. Sultan Qaimuddin No.17, Kendari, 39111 \\ e-mail: smsulbahri1@gmail.com
}

\begin{abstract}
Abstrak: Tulisan ini mengkaji ketahanan pesantren dalam perspektif teori struktural fungsional. Metode yang digunakan adalah deskriptif-analitis dengan pendekatan sosiologis. Studi ini menyimpulkan bahwa sistem pendidikan pesantren dalam perspektif teori struktur fungsionalisme memiliki daya tahan karena memiliki empat fungsi, yaitu adaptasi pesantren dengan lingkungan masyarakat; tujuan pesantren membentuk kepribadian santri yang berakhlak; integrasi pesantren baik secara sistem kelembagaan maupun kurikulum, pemeliharaan pola kultural sistem nilai di pesantren yang kental dengan keikhlasan, kemandirian, kesederhanaan, kejujuran, ukhuwah Islamiyah dan jiwa kebebasan. Bahkan pesantren mempunyai kepemimpinan kiai dalam proses pendidikan. Karena itu, pesantren yang memiliki daya tahan adalah yang melakukan empat sistem fungsi struktural ini. Jika tidak, sistem pendidikan pesantren tidak mempunyai daya tahan yang kuat, bahkan akan tergusur sebagai lembaga pendidikan Islam.
\end{abstract}

\begin{abstract}
The Perspective of Structural-functional Theory on the Sustainability of Pesantren's Education System. This paper examines the sustainability of Islamic boarding school system. The method used descriptive-analytic with sociology approach. This study found that the resilience of pesantren education system in the perspective of the theory of structural functionalism has the durability and strong continuities due to its four functions, namely; adaptability with with the community, goal attainment form students to have a certain personality, integration of institutional system and curriculum, and maintenance of cultural patterns value systems. In addition, the schools have kiai leadership in the process of boarding school education. Therefore, a large boarding school that has the durability and continuities are schools that perform four functions of structural systems. If not, then certainly the pesantren education system does not have a strong resistance, even to be displaced as Islamic educational institutions.
\end{abstract}

Kata Kunci: ketahanan, sistem pendidikan pesantren, sturktural fungsional 


\section{Pendahuluan}

Pesantren (Islamic boarding school) banyak diteliti para ilmuwan baik di kalangan peneliti ilmu agama Islam, ilmu sosial, maupun antropologi. ${ }^{1}$ Namun penelitian-penelitian tersebut belum mengungkap semua rahasia kenapa pesantren mampu bertahan (tetap survive) sampai saat ini. ${ }^{2}$ Hal ini diakui Ronald Alan Lukens Bull dalam penelitiannya, bahwa pesantren ternyata mampu eksis dalam era globalisasi ini. ${ }^{3}$ Karena pesantren lembaga pendidikan asli Indonesia, ${ }^{4}$ yang tergolong unik dan menampilkan sistem pendidikan tradisional ${ }^{5}$ dengan ciri khas kitab kuning sebagai kajian utamanya. ${ }^{6}$ Menurut Martin van Bruinessen, pesantren memiliki tradisi agung (great tradition) dalam sistem pendidikan Islam di Indonesia, ${ }^{7}$ yang mempunyai keunggulan baik dalam tradisi keilmuannya maupun pada transmisi dan internalisasi moralnya. Di sisi lain, pesantren juga memainkan peran pemberdayaan (empowerment) dan transformasi civil society secara efektif. ${ }^{8}$ Bahkan pesantren berfungsi sebagai satu elemen determinan dalam struktur piramida sosial masyarakat Indonesia. Dalam bahasa Sahal Mahfudh, pesantren sebagai cerminan perpaduan antara pesantren dan lingkungan sosial ${ }^{9}$ serta memberikan konstribusi yang signifikan terhadap perubahan sosial ${ }^{10}$ misalnya dalam program transmigrasi, sosialisasi sistem keluarga berencana, gerakan sadar lingkungan, bahkan dalam pembangunan infra struktur dan supra struktur dalam perbaikan prasarana fisik dan pembangunan masyarakat desa, penyelenggaraan poliklinik bagi anggota masyarakat sekitarnya. ${ }^{11}$

${ }^{1}$ Raehani, "Islam dan Kemajemukan Indonesia: Studi Kasus Pesantren dan Pendidikan Multikultural," dalam Annual Conference on Islamic Studies (ACIS) ke-10, Banjarmasin: 2011), h. 386.

${ }^{2}$ Ahmad Tafsir, Ilmu Pendidikan Islam (Bandung: Remaja Rosdakarya, 2012), h. 289.

${ }^{3}$ Penelitian Bull ini juga telah merumuskan tipologi pesantren yang terdiri dari tiga tipe, yaitu pesantren salafiyah, modern dan terpadu. Lihat Zaenal Khafidin, "Model Pendidikan Pesantren Madrasah," dalam Jurnal Penelitian, Vol. 2, No. 1, 2008), h. 249.

${ }^{4}$ Amin Haedari, "Peran Strategis Pesantren, Madrasah dan Sekolah," dalam Jurnal Pondok Pesantren Mihrab, Vol. II, No. 1, Juli, 2007, h. 34.

${ }^{5}$ Karel A. Steenbrink, Pesantren, Madrasah, Sekolah: Pendidikan Islam Kurun Modern (Jakarta: LP3ES, 1986), h. 1-27.

${ }^{6}$ Fadlil Munawwar Mansur, "Kekayaan Budaya Pesantren," dalam Jurnal Humaniora, Vol. XIV, No. 2/2004, h. 20.

${ }^{7}$ Martin van Bruinessen, Kitab Kuning, Pesantren dan Tarekat: Tradisi-tradisi Islam di Indonesia (Bandung: Mizan, 2012), h. 17.

${ }^{8}$ Mardiyah, "Kepemimpinan Kiai dalam Memelihara Budaya Organisasi: di Pondok Pesantren Modern Gontor, Lirboyo Kediri, dan Tebuireng Jombang," dalam Jurnal Tsaqafah, Vol. 8. No. 1, April 2012, h. 67.

${ }^{9}$ Sahal Mahfudh, Nuansa Fiqih Sosial (Yogjakarta: LKiS, 1994), h. 342.

${ }^{10} \mathrm{Di}$ bagian lain tulisannya menjelaskan ada tiga unsur pokok yang membangun subkultur pesantren: pola kepemimpinan, literatur universal, yang dipelihara beberapa abad dan sistem nilainya. Abdurrahman Wahid, Bunga Rampai Pesantren: Kumpulan Karya Tulis (Jakarta: Dharma Bhakti, 1984), h. 9.

${ }^{11}$ Dawam Rahardjo, "Mozaik Pesantren," dalam Jurnal Modernisasi Manajemen Pendidikan Pesantren, Edisi 02/Tahun I/Nopember 2005, h. 17. 
Pesantren dalam perkembangan selanjutnya ${ }^{12}$ tidak hanya sebatas fungsi yang disebutkan di atas, tetapi pesantren juga dipandang sebagai lembaga pendidikan keagamaan yang memiliki moralitas tinggi bahkan nilai moralitas ini menyebar ke tengah-tengah masyarakat dengan brand image pesantren sebagai pioner karakter bangsa (character building). Berangkat dari realitas di atas, tulisan ini akan berusaha menjawab tentang bagaimana ketahanan sistem pendidikan pesantren dalam pandangan teori struktural fungsional. Untuk menjawab pertanyaan tersebut, akan digunakan metode deskriptif-analitis dengan pendekatan sosiologi dan content analysis. Karena itu, tujuan dari kajian ini adalah untuk mengetahui ketahanan sistem pendidikan pesantren dalam pandangan teori struktural fungsionalisme.

\section{Ketahanan Sistem Pendidikan Pesantren}

Sejak adanya arus modernisasi atau perubahan pendidikan Islam di kawasan dunia Muslim, tidak banyak lembaga-lembaga pendidikan tradisional Islam seperti pesantren yang mampu bertahan. ${ }^{13}$ Kebanyakan lenyap dan tergusur karena adanya ekspansi dan transformasi sistem pendidikan umum. ${ }^{14}$ Namun pesantren banyak menghadapi tantangan dan rintangan sejak zaman kolonial Belanda, kemerdekaan, Orde Baru hingga masa sekarang seperti marginalisasi peran pesantren, penciptaan stigma jelek, dan perluasan pendidikan sekular. Tantangan dari sistem pendidikan Belanda, yang memperkenalkan sistem pendidikan sekolah bagi anak-anak Indonesia, dengan mendirikan Sekolah Rakyat (volkscholen) atau disebut juga sekolah desa (nagari) dengan masa belajar 3 tahun. ${ }^{15}$ Selain itu juga datang dari eksponen tokoh sekular pendidikan Indonesia yang memberikan stigma jelek dan menginginkan agar pesantren dihapuskan sebagai bagian dari pendidikan nasional. ${ }^{16}$

Dalam perspektif historis, perubahan orientasi pesantren yang bervariasi telah terjadi pada awal abad ke-20. Beberapa tokoh Muslim modernis Indonesia yang berlatar belakang pendidikan dari Timur Tengah melakukan modifikasi terhadap model pendidikan sekulaer

\footnotetext{
${ }^{12}$ Ma'ruf Hidayat, Kinerja Manajmen dan Proses Pembelajaran pada Pondok Pesantren Ibnul Amin Pamangkih (Darussalam Martapura: 2002), h. 2.

${ }^{13}$ Azyumardi Azra, Pendidikan Islam: Tradisi dan Modernisasi Menuju Milenium Baru (Jakarta: Logos Wacana, 2000), h. 95.

${ }^{14}$ Untuk memperjelas argumen di atas dikemukakan nasib atau pengalaman beberapa daerah pada kawasan dunia Muslim seperti Turki dan Mesir cukup memadai untuk menggambarkan proses memudarnya dan lenyapnya sistem pendidikan tradisional Islam (madrasah dan kuttâb) dalam gelombang modernisasi yang diterapkan negara-negara tersebut.

${ }^{15}$ Azra, Pendidikan Islam: Tradisi dan Modernisasi, h. 97.

${ }^{16}$ Pendapat negatif terhadap pendidikan pesantren misalnya datang dari Sutan Takdir sebagai eksponen pendidikan Belanda yang menyatakan bahwa sistem pendidikan pesantren harus ditinggalkan atau setidaknya ditransformasikan sehingga dapat memberikan kemajuan secara intelektual kepada kaum Muslim. Jika pesantren tidak dihapus menurut sutan Takdir, maka akan membiarkan umat Islam dalam keterbelakangan dan kebekuan berfikir. Azyumardi Azra, "Pesantren: Kontinuitas dan Perubahan," dalam Nurcholish Madjid, Bilik-Bilik Pesantren: Sebuah Potret Perjalanan (Jakarta: Paramadina 1997), h. xiii.
} 
Belanda. ${ }^{17}$ Mereka tidak menolak sepenuhnya yang datang dari Belanda, tetapi mengadaptasi sebagian yang dianggap baik seperti sistem madrasah yang berbeda dari lembaga pendidikan tradisional sebelumnya. Materi ajarnya yang terpusat pada al-Qur'an, hadis, tafsir, kitab kuning, serta nahwu dan saraf, ditambah kurikulum umum seperti aljabar, dan ilmu bumi. ${ }^{18}$

Dalam konteks ini, muncullah dua bentuk lembaga pendidikan modern Islam. Pertama, sekolah-sekolah umum model Belanda diberi muatan pengajaran Islam, seperti Sekolah Adabiyah yang dirikan Abdullah Ahmad di Padang pada tahun 1909, dan sekolah-sekolah Muhammadiyah. Kedua, madrasah-madrasah modern yang secara terbatas mengadopsi substansi dan metodologi pendidikan modern Belanda, seperti Sekolah Diniyah Zainuddin Labay el-Yunusiah atau Sumatera Thawalib, madrasah yang didirikan al-Jam'iyatul alKhairiyah, dan madrasah yang didirikan organisasi al-Irsyad. ${ }^{19}$

Pesantren di Jawa juga memberikan respons terhadap kemunculan ekspansi sistem pendidikan modern. Dengan meminjam istilah Karel A. Steenbrink, pada saat yang sama menolak sambil mengikuti ${ }^{20}$ langkah kaum reformis agar pesantren bisa tetap bertahan, pesantren melakukan sejumlah teori akomodasi dan penyesuaian yang mereka anggap tidak hanya akan mendukung kontiniutas pesantren, tetapi juga bermanfaat bagi para santri, seperti sistem penjenjangan, kurikulum yang lebih jelas, dan sistem klasikal. ${ }^{21}$

Pesantren yang pertama kali memberikan respons terhadap modernisasi adalah pesantren Mambaul Ulum di Surakarta yang didirikan oleh Susuhunan Pakubuwono pada tahun 1906. Pesantren ini menjadi perintis masuknya pendidikan umum di pesantren dan me-masukkan mata pelajaran membaca dengan tulisan latin, aljabar dan berhitung dalam kurikulum pendidikannya. ${ }^{22}$

Pesantren Tebuireng di Jombang pada tahun 1916 juga mengikutinya dengan mendirikan sebuah Madrasah Salafiyah yang tidak hanya mengadopsi sistem pendidikan modern, tetapi juga memasukkan beberapa pelajaran umum seperti berhitung, bahasa Melayu, ilmu bumi, dan menulis dengan huruf Latin ke dalam kurikulumnya. ${ }^{23}$ Bahkan Dhofier menyatakan bahwa mulai tahun 1919 pendidikan pesantren tidak hanya mengajarkan pendidikan agama Islam semata, tetapi juga mata pelajaran non agama seperti pelajaran

\footnotetext{
${ }^{17}$ Mundzier Suparta, Perubahan Orientasi Pondok Pesantren Salafiyah terhadap Perilaku Keagamaan Masyarakat Keagamaan (Jakarta: Asta Buana Sejahtera, 2009), h. 69.

${ }^{18}$ Ibid.

${ }^{19}$ Deliar Noer, Gerakan Modern Islam di Indonesia 1900-1942 (Jakarta: LP3ES, 1998), h. 38-104

${ }^{20}$ Steenbrink, Pesantren, Madrasah, Sekolah, h. 38-104.

${ }^{21}$ Mohammad Muchlis Solihin, "Modenisasi Pendidikan Pesantren," dalam Jurnal Tarbiyah, Vol. 6, No. 1, Juni 2011, h. 38.

${ }^{22}$ Azra, Pendidikan Islam: Tradisi dan Modernisasi, h. 100.

${ }^{23}$ Zamakhsyari Dhofier, Tradisi Pesantren: Studi tentang Pandangan Kiai (Jakarta: LP3ES,
} 2011), h. 100-126. 
bahasa Indonesia, matematika dan ilmu bumi yang dilaksanakan di madrasah. ${ }^{24}$ Masuknya mata pelajaran umum di pesantren Tebuireng, sebagai pesantren yang tersohor di Jawa dan Madura, telah menginspirasi pesantren-pesantren lainnya untuk melakukan langkah yang sama. Mulai saat itu hingga sekarang, banyak pesantren yang sebelumnya hanya menyelenggarakan pembelajaran kitab-kitab Islam klasik, sekarang telah melaksanakan sistem pendidikan madrasah dan sekolah dengan mengikuti kurikulum pemerintah. ${ }^{25}$

Respons dunia pesantren terhadap tantangan modernisasi secara monumental terlihat atas didirikannya Pondok Modern Gontor pada tahun $1926 .{ }^{26}$ Pondok pesantren ini, selain memasukkan sejumlah mata pelajaran umum ke dalam kurikulum, juga mendorong para santri untuk mempelajari bahasa Inggris, selain bahasa Arab, dan melaksanakan sejumlah kegiatan ekstra-kurikuler seperti olah raga dan kesenian. Bahkan secara kelembagaan, Gontor telah melakukan terobosan dengan mewakafkan seluruh asetnya kepada Badan Wakaf agar ketika para pendiri meninggal dunia, pesantren tidak diwarisi oleh keluarga seperti terjadi di banyak pesantren, tetapi badan wakaf yang meneruskan estafet kepemimpinan pondok pesantren. ${ }^{27}$ Akibat dari perubahan ini menurut Haidar, lahirlah sistem pendidikan klasikal di pesantren, yang kemudian diiringi dengan masuknya mata pelajaran umum. ${ }^{28}$ Bahkan dalam perkembangan terakhir saat ini, telah banyak pesantren yang mengasuh sekolah umum dan madrasah, di samping tetap mempertahankan sistem pesantren tradisional. ${ }^{29}$

Teori akomodasi tersebut memunculkan problema dan perubahan di dalam sistem pendidikan pesantren dengan penyelenggaraan madrasah dan sekolah umum yang ada di dalamnya. Problem itu adalah kurangnya porsi pengajian kitab-kitab keislaman klasik dan waktu belajar santri lebih banyak dialokasikan di madrasah dan sekolah, sehingga mengakibatkan turunnya kemampuan santri dalam memahami kitab-kitab tersebut. ${ }^{30}$ Bahkan menurut Ahmad Tafsir, dengan diselenggarakannya madrasah Tsanawiyah, Aliyah dan SMP serta SMA di dalam sistem pendidikan pesantren, terdapat keuntungan dan kerugian

${ }^{24}$ Ibid.

${ }^{25}$ Steenbrink, Pesantren, Madrasah, Sekolah, h. 120.

${ }^{26}$ Pendiri tiga bersaudara kiai Ahmad Sahal, Kiai Zainuddin Fanani dan Kiai Zarkasyi.

${ }^{27}$ Abdullah Syukri Zarkasyi, Gontor dan Pembaharuan Pendidikan Pesantren (Jakarta: Rajawali, 2005), h. 45-55.

${ }^{28}$ Haidar Putra Daulay, Historisitas dan Eksistensi, Pesantren, sekolah dan Madrasah (Yogyakarta: Tiara Wacana, 2000), h. 26.

${ }^{29}$ Ibid., h. 26.

${ }^{30}$ Fenomena ini, misalnya terjadi di pondok Pesantren Darul Ulum di bawah kepemimpinan Kiai Mustain Romli dan pondok pesantren Tebuireng di bawah kepemimpinan kiai Haji Yusuf Hasyim. Pada masa itu, kedua pesantren tersebut menyelenggarakan sistem pendidikan madrasah dan sekolah formal dari TK hingga perguruan tinggi. Dengan penyelenggaraan pendidikan formal tersebut, terjadilah pengurangan waktu santri dalam mengikuti pengajian kitab, karena pesantren, dengan madrasah dan sekolah formalnya, dituntut untuk memenuhi target kurikulum yang diprogramkan Kementerian Agama dan Kementerian Pendidikan Nasional. Lihat Solihin, "Modernisasi Pendidikan Pesantren", h. 44. 
bagi pesantren. Hal ini terlihat jumlah santri pesantren semakin merosot, sehingga kekuatan pesantren berkurang, sementara itu, jumlah siswa Tsanawiyah, Aliyah dan SMP serta SMA semakin banyak. Mereka ini hampir seluruhnya bukan santri. Mereka bersekolah di kompleks pesantren. Santri adalah mereka yang mondok di pesantren dan mengaji kitab kuning, atau mereka yang tidak mondok (disebut santri kalong), tetapi mengaji kitab kuning. ${ }^{31}$

Penyelenggaraan pendidikan madrasah dan sekolah umum di institusi pesantren lebih diminati dari pada pendidikan pesantrennya. Teori ini menguatkan tesis Karel A. Steenbrink yang menjelaskan bahwa ketika pendidikan pesantren diperkenalkan lembaga pendidikan yang lebih teratur dan modern, ternyata lembaga pendidikan tradisional tidak begitu laku dan banyak ditinggalkan siswanya. ${ }^{32}$

Teori Karel A. Steenbrink di atas tidak sepenuhnya benar, karena masih banyak pesantren yang melakukan modernisasi tetapi tetap bertahan pada jati diri pesantren tanpa kehilangan esensi dari pesantren itu sendiri. Hal ini dibuktikan oleh Ali Anwar dalam penelitiannya, Pembaharuan Pendidikan Pesantren Lirboyo di Kediri. ${ }^{33}$ Hasil penelitiannya membuktikan bahwa tidak semua pesantren yang melakukan pembaharuan menghilangkan fungsi utama pesantren, yaitu transmisi ilmu keislaman, pemeliharaan tradisi Islam dan penciptaan kader-kader ulama. Salah satunya adalah Pesantren Lirboyo (sebagai tempat penelitian) yang menyelenggarakan pendidikan madrasah Diniyah Hidayatul Mubtadi'in dan pendidikan yang lebih modern seperti MTs dan MA dan bahkan SD, SMP, dan SMA arRisalah. ${ }^{34}$

Menanggapi hal itu, Azyumardi Azra mengingatkan para eksponen pesantren jangan tergesa-gesa mentransformasikan kelembagaan pesantren menjadi lembaga pendidikan modern Islam sepenuhnya, tetapi sebaliknya cenderung mempertahankan kebijakan dan hati-hati (cautious policy) menerima pembaharuan pendidikan Islam dalam skala terbatas, supaya pesantren tetap mempunyai eksistensi. ${ }^{35}$ Lain halnya dengan Mastuhu yang menjelaskan, bahwa jika pendidikan pesantren ingin melakukan modernisasi dan menjadi center of excellence bagi pengembangan pesantren, maka ada beberapa hal yang harus dilakukan. Pertama, visi pesantren yang cenderung berorientasi kepada pengembangan moral diperbaharui dengan visi yang lebih mengacu kepada persoalan bagaimana menguasai sains

${ }^{31}$ Tafsir, Ilmu Pendidikan Islam, h. 300.

${ }^{32}$ Steenbrink, Pesantren, Madrasah, Sekolah, h. 122.

${ }^{33}$ Ali Anwar, "Pembaharuan Pendidikan di Pesantren Lirboyo Kediri" (Disertasi UIN Syarif Hidayatullah, 2008), h. 165-166.

${ }^{34}$ Hal tersebut disebabkan, antara lain, Pertama, lembaga pendidikan tradisional ini masih sesuai dengan kecenderungan sosial-kultural yang menganggap paham Ahli Sunnah wal-Jama'ah. Kedua, lembaga pendidikan tradisional ini berhasil mengantar santrinya untuk menguasai kitab kuning. Ketiga, dikarenakan tradisi yang dikembangkan dengan lestarinya kharisma kiai. Bahkan penelitian ini menemukan bahwa dari 9.163 santri Lirboyo saat ini, $5.720(62,42 \%)$ hanya mendalami kitab kuning di Madrasah Hidâyatul Mubtadi'în.

${ }^{35}$ Azra, Pendidikan Islam: Tradisi dan Modernisasi, h. 101. 
dan teknologi. Kedua, dikotomi ilmu umum dan agama yang merupakan warisan politik dan budaya kolonial tidak relevan lagi. Sebaliknya, justru pesantren mulai memperkenalkan sains dan teknologi kepada para santri. Ketiga, pesantren tetap konsisten bahwa pandangan pintu ijtihad tidak pernah tertutup. Bahkan pesantren bisa menjadi sebuah institusi pendidikan modern yang mampu mengembangkan ilmu pengetahuan dan teknologi (Iptek) Islami. ${ }^{36}$

Pernyataan di atas diakui Pupuh Faturrahman, ${ }^{37}$ bahwa aspek keterpaduan dalam dunia pesantren dengan modernisasi dapat dilihat dan dibuktikan di antaranya sebagai berikut. Pertama, keterpaduan pelaksanaan pendidikan, kecerdasan kognitif, afektif, dan psikomotorik, dapat dilaksanakan secara seimbang melalui proses belajar dipesantren. Kedua, pesantren sebagai full day school system, artinya pada pesantren berlaku konsep tiada waktu tanpa belajar atau pendidikan adalah kehidupan. Ketiga, hubungan keterpaduan antar lembaga pendidikan pesantren dengan orangtua santri dan masyarakat telah terbiasa berjalan dengan baik. Keterpaduan antara teori dan konsep ilmu pengetahuan (pengetahuan umum dan agama) yang dipelajari dan dihafalkan langsung dapat dipraktikkan (diamalkan) dalam kehidupan sehari-hari. Pelaksanaan evaluasi dan penilaian terhadap hasil pendidikan diwujudkan dari keberhasilan dan keunggulan watak sebagai kepribadian yang dilandasi agama.

Institusi pesantren saat ini sudah dapat melakukan berbagai perubahan dan peran yang demikian besar dalam konstalasi percaturan politik, ekonomi, pendidikan, budaya, seni, di samping peran keagamaan. ${ }^{38}$ Menurut Said Aqil Siradj, ada tiga ${ }^{39}$ kekurangan pesantren yang perlu dibenahi bila pesantren ingin menjadi lembaga pendidikan yang berkualitas. Pertama, pesantren mampu melepaskan diri dari kesan dan citra kerajaan kecil. Artinya, dalam pesantren ditumbuhkan sifat keterbukaan, kebebasan berpikir dan berpendapat, kemandirian, kolektifitas dan menerima secara opensif berbagai gagasan pembaharuan dari luar. Kedua, independensi dan otonomi pesantren yang selama ini ada diperkuat dan diarahkan sebagai basis pemberdayaan serta penguatan masyarakat untuk mengimbangi kekuatan negara. Ketiga, kurikulum pesantren dirombak, metodologi pemikiran menjadi fokus utama dan santri dikembalikan kepada literatur klasik. Rahmat Pulung menambahkan bahwa ada beberapa titik kritis yang menghambat modernisasi pendidikan pesantren. ${ }^{40}$ Pertama, kepemimpinan pesantren secara kaku masih terpola dengan kepemimpin-

${ }^{36}$ Mastuhu, Memberdayakan Sistem Pendidikan Islam (Jakarta: Logos Wacana Ilmu, 1999), h. 276.

${ }^{37}$ Pupuh Faturahaman, Keunggulan Pendidikan Pesantren: Alternatif Sistem Pendidikan Terpadu Abad XXI (Bandung: Tunas Nusantara, 2000), h. 132-139.

${ }^{38}$ Abuddin Nata, Tokoh-tokoh Pembaharuan Pendidikan Islam di Indonesia (Jakarta: RajaGrafindo Persada, 2000), h. 349.

${ }^{39}$ Edy Supriyono, "Pesantren di Tengah Arus Globalisasi," dalam M. Affan Hasyim, et al., Menggagas Pesantren Masa Depan (Yogyakarta: t.p., 2008), h. 67.

${ }^{40}$ Namun demikian, ada tantangan baru yang dihadapi institusi pesantren saat ini, yang antara lain: Pertama, image pesantren sebagai sebuah lembaga pendidikan yang tradisional, 
an yang sentralistik dan hierarkis yang berpusat pada satu kiai. Kedua, kurang adanya improvisasi metodologi. Proses transmisi itu hanya melahirkan penumpukan keilmuan. Perbaikan metodologi dan pembahasan masalah kekinian sangat diperlukan agar pondok pesantren tidak terlepas dari lingkungan. Ketiga, terjadinya disorientasi pondok yang tidak mampu mendefinisikan dan memosisikan dirinya di tengah realitas sosial yang berubah demikian cepat. ${ }^{41}$

Pesantren seharusnya dapat mengikuti modernisasi dalam perkembangan dan perubahan zaman dengan tidak melupakan jati diri pesantren. Transformasi di tubuh pesantren baik kurikulum maupun dalam metode pembelajarannya, tidak harus menghilangkan jati dirinya sendiri. ${ }^{42}$ Karena itu, dalam menghadapi perubahan yang begitu pesat, sekurang-kurangnya pesantren harus melakukan transformasi fundamental pada institusi dan kurikulumnya, ${ }^{43}$ sehingga pesantren adalah tempat untuk mencetak santri yang diharapkan baik agamanya dan pandai menghadapi persoalan umat. ${ }^{44}$ Peran semacam ini, dimung-kinkan pesantren menjadi lembaga pengkaderan bagi santri yang kelak siap terjun di masyarakat. Bahkan pengembangan sistem pendidikan pesantren dalam melahirkan sumber daya manusia yang unggul dilakukan beberapa hal. Pertama, pesantren mampu untuk mengembangkan jaringanjaringan kerjasama (networking). Kedua, kerjasama (team work). Ketiga, berkaitan erat dengan

tidak modern, informal, dan bahkan diklaim sebagai lembaga yang melahirkan teroris yang mempengaruhi pola pikir masyarakat. Kedua, sarana dan prasarana penunjang yang terlihat masih kurang memadai. Ketiga, sumber daya manusianya bidang keagamaan tidak dapat diragukan lagi, tetapi dalam rangka meningkatkan eksistensi dan peranan pondok pesantren di bidang kehidupan sosial masyarakat, diperlukan perhatian serius. Keempat, aksebilitas dan networking, merupakan salah satu kebutuhan pengembangan pesantren. Kelima, manajemen kelembagaan, merupakan unsur penting dalam pengelolaan pesantren. Keenam, kemandirian ekonomi kelembagaan. Ketujuh, kurikulum yang berorientasi life skill santri dan masyarakat.

${ }^{41}$ Rahmat Pulung Sudibyo, "Integrasi, Sinergi dan Optimalisasi dalam Rangka Mewujudkan Pondok Pesantren Sebagai Pusat Peradaban Muslim Indonesia," Jurnal Salam, Vol 13, No. 2, 2010, h. 58-59.

${ }^{42} \mathrm{M}$. Annas Mahduri, et al., Pesantren dan Pengembangan Ekonomi Umat: Pesantren al-Ittifaq dalam Perbandingan (Jakarta: Depag RI, 2002), h. 6.

${ }^{43}$ Transformasi institusional adalah terjadinya penambahan-penambahan institusi yang secara tradisional berada di luar peran dan fungsi pesantren. Jika disebutkan bahwa peran dan fungsi pesantren sejak masa pertumbuhan Islam adalah sebagai pusat pengembangan, penyiaran, pendidikan dan pendalaman ilmu-ilmu keislaman, maka yang termasuk peran dan fungsi tambahan pesantren meliputi pendirian sekolah-sekolah umum, kursus bahasa asing, pusat pelatihan manajemen, komputer, agrobisnis, perkebunan, perlautan \& kehutanan. Lihat Suyoto, "Pesantren dalam Alam Pendidikan Nasional," dalam M. Dawam Raharjo (ed.), Pesantren dan Pembaharuan (Jakarta: LP3ES, 1974), h. 61-65. Konsewensi dari transformasi institusional ialah keharusan pesantren melakukan transformasi kurikulum. Transformasi ini lebih menyangkut pada posisi materi dan cakrawala berpikir yang diajarkan kepada para santri. Posisi ilmu-ilmu ini sebagai pengkayaan dan pengembangan. Jika pada mulanya pesantren secara tradisional hanya mengajarkan sebatas pada ilmu keislaman seharusnya pesantren juga mengajarkan ilmu-ilmu umum.

${ }^{44}$ Sri Hasingsih, "Peran Strategis Pesantren, Madrasah, dan Sekolah Islam di Indonesia," dalam el-Tarbawi: Jurnal Pendidikan Islam, No. 1, Vol. 1, 2008, h. 36. 
prinsip kerja sama tersebut, ialah cinta kepada kualitas yang tinggi. Pesantren yang unggul adalah pesantren yang bisa mengembangkan dirinya dan melaksanakan tugasnya sebagai lembaga pendidikan. Keempat, perkembangan secara eksponensial pada ilmu pengetahuan telah mengubah prinsip-prinsip belajar manusia yang harus dilaksanakan seumur hidup. Salah satu tugas berat pesantren sebagai lembaga pendidikan adalah mampu melahirkan manusia belajar secara mandiri, sesuai dengan konsep pendidikan sepanjang hayat. ${ }^{45}$

Teori pengembangan pesantren ternyata memunculkan problematika bagi pondok pesantren dalam melakukan modernisasi. Pertama, banyak lembaga pesantren yang tergusur sejak dilancarkannya perubahan atau modernisasi di berbagai kawasan dunia Muslim dan sebagian lembaga pesantren tidak mampu bertahan. Kedua, banyak pesantren mengalami transformasi sehingga sebagian telah memasukkan lembaga pendidikan umum. Ketiga, lembaga pesantren mengalami penurunan animo masyarakat sehingga mengakibatkan jumlah santri menurun setelah menyesuaikan diri dengan mengadopsi sedikit banyak isi dan metodologi pendidikan umum. ${ }^{46}$ Keempat, sebagian pesantren enggan dengan perubahan (dan memilih menjaga budaya lama) dengan menolak masuknya kebijakan pemerintah melalui Kementerian Agama (Kemenag) dan Kementerian Pendidikan dan Kebudayaan (Kemendibud) karena khawatir akan kehilangan karakter budaya organisasi lembaganya yang sudah mapan dan dipercaya masyarakat. ${ }^{47}$

Perubahan yang dilakukan pesantren menyebabkan terjadinya pergeseran tujuan pendidikan pesantren dari universalisasi pandangan hidup yang dilandasi suatu nilai tertentu berubah menjadi pencapaian prestasi skolastik. ${ }^{48}$ Kemerosotan identitas pendidikan pesantren juga dilontarkan banyak pihak termasuk kalangan pesantren itu sendiri. Kalangan terakhir ini bahkan mengkhawatirkan, bahwa kalau eksperimen yang berorientasi kepada kekinian itu terus berlanjut, maka pesantren akan tidak bisa memenuhi fungsi pokoknya, yaitu menghasilkan manusia-manusia santri dan sekaligus melakukan reproduksi ulama.

Secara implisit menyarankan bahwa pesantren perlu mengkaji ulang secara cermat dan hati-hati berbagai gagasan untuk mengorientasikan pesantren pada tantangan modernisasi, sebab tidak mungkin orientasi semacam itu akan menimbulkan implikasi negatif terhadap eksistensi dan fungsi pondok pesantren itu sendiri. Harus dipahami bahwa dengan menyatakan hal ini, tidak berarti pesantren harus tidak peduli sekali terhadap perkembangan di luar dunianya, sebaliknya dapat memproduksi calon ulama yang berwawasan luas.

${ }^{45}$ H.A.M. Tilaar, Pendidikan dan Pembangunan Nasional Menyongsong Abad XXI (Jakarta: Balai Pustaka, 1998), h. 65-74.

${ }^{46}$ Azra, Pendidikan Islam: Tradisi dan Modernisasi, h. 95.

${ }^{47}$ Pondok pesantren Lirboyo Kediri dan PM Gontor Ponorogo yang tetap mempertahankan karakter budaya organisasi yang sudah terbentuk dan dipercaya masyarakat sampai sekarang tetap tidak mau menerima kebijakan dari Kementerian Agama dan Kementerian Pendidikan dan Kebudayaan dengan dibuktikan tetap menolak adanya kebijakan UN (Ujian Nasional) di dua pesantren tersebut.

${ }^{48}$ Wahid, Membangun Tradisi Pesantren, h. 106. 
Dilihat dari konteks perkembangan dunia yang semakin berkembang, maka fungsi pokok pendidikan pesantren yang disebutkan tadi, justru semakin relevan di tengah arus globalisasi yang adalah bagian dari imprialisme budaya (cultural imperialism) Barat terhadap budaya-budaya lain, yang melanggar nilai-nilai moral agama. ${ }^{49}$ Pesantren harus memainkan perannya sebagai cultural brokers (pialang budaya) dan kemampuannya dalam mengontrol perubahan nilai. ${ }^{50}$ Perubahan pesantren sebagai salah satu lembaga tradisional Islam dan lembaga pendidikan masyarakat yang diharapkan menjadi alternatif pembangunan yang berpusat pada masyarakat itu sendiri (people-centered development) dan sekaligus sebagai pusat pengembangan pembangunan yang berorientasi pada nilai (value-oriented development). ${ }^{51}$ Karena itu, suatu keharusan untuk melihat kembali eksistensi pondok pesantren, terutama dalam sistem keorganisasiannya. Pesantren diharapkan tidak lagi sekadar memainkan ketiga fungsi tradisional tadi, tetapi juga menjadi pusat penyuluhan kesehatan, pengembangan teknologi tepat guna bagi masyarakat di sekitarnya. Dalam konteks terakhir, terlihat semakin banyak pesantren yang terlibat dalam aktivitas-aktivitas vocational dan ekonomi. ${ }^{52}$ Dengan demikian, pesantren bukan hanya mampu bertahan tetapi lebih dari itu, dengan penyesuaian, akomodasi dan konsesi yang diberikannya, pesantren juga mampu mengembangkan diri, dan bahkan kembali menempatkan diri pada posisi yang penting dalam sistem pendidikan nasional Indonesia secara keseluruhan. ${ }^{53}$

Banyak para peneliti yang berhasil membuktikan bahwa daya tahan sistem pendidikan pesantren itu terletak pada tradisinya seperti, penelitian Martin van Bruinessen Kitab Kuning, Pesantren, dan Tarekat: Tradisi-Tradisi Islam di Indonesia. Dalam pandangan Bruinessen, pesantren telah sukses membangun tradisi agung (great tradition) dalam pengajaran agama Islam berbasis kitab-kitab klasik yang populer dengan sebutan kitab kuning. Tradisi yang dikembangkan pesantren memiliki keunikan dan perbedaan jika dibandingkan dengan tradisi dari entitas Islam lainnya di Indonesia seperti kaum modernis. Keunikan pesantren tentu terlihat pada kegigihannya merawat tradisi keilmuan klasik yang nyaris terabaikan oleh kaum modernis.

Penelitian Zamakhsari Dhofier tentang Tradisi Pesantren: Studi tentang Pandangan Hidup Kiai (1994) yang memberikan gambaran pesantren dengan menawarkan cara pandang baru yang disebut continuity and change (kesinambungan dan perubahan). Melalui sudut

${ }^{49}$ Adian Husain, Wajah Peradaban Barat: dari Hegemoni Kristen ke Dominasi SekularLiberal (Jakarta: Gema Insani, 2005), h. 20-27.

${ }^{50}$ Tafsir, Ilmu Pendidikan Islam, h. 296.

${ }^{51}$ Azra, Pendidikan Islam: Tradisi dan Modernisasi, h. 139.

${ }^{52}$ Ibid, h. 105.

${ }^{53}$ Ekspansi pesantren juga terlihat dari pertumbuhan pesantren yang semula rural based institution menjadi juga lembaga pendidikan urban. Lihatlah kemunculan sejumlah pesantren di kota seperti Jakarta, Bandung, Medan Pekan Baru \&Yogyakarta. Dhofier menjelaskan di antara pesantren perkotaan seperti Dâr al-Najâh dan Al-Shiddiqiyah di Jakarta, Pesantren Nûrul Hakîm, al-Kautsar, dan Dâr al-'Arafah di Medan, dan Dâr al-Hikmah di Pekan Baru. 
pandang epistemik ini, Dhofier berhasil menunjukkan bahwa kreativitas pesantren dalam merespons perubahan dengan tetap merujuk pada tradisi keilmuan klasik suatu cara pandang yang diabaikan oleh peneliti pesantren yang berasal dari luar pesantren. Bahkan Dhofier menyebut tiga nama sebagai sasaran kritik. Dua nama yang disebut pertama adalah Clifford Geertz dan Alan Samson yang menggambarkan dunia pesantren cukup fatal dengan menggolongkan pesantren sebagai Islam kolot yang akrab dengan elemen-elemen sinkretis yang bertentangan dengan Islam. Anehnya, kesalahan cara pandang peneliti asing dilakukan pula oleh peneliti dari Indonesia, yakni Deliar Noer terhadap dunia pesantren. Menurut Dhofier, cara pandang Deliar Noer terhadap pesantren tidak jauh berbeda dengan Samson dan Geertz yang cenderung memosisikan pesantren secara dikotomik: tradisionalisme pesantren di satu pihak dengan modernisme di pihak lain.

Kajian ini juga dilakukan Horikoshi (1976) yang berjudul Kiai dan Perubahan Sosial. Temuan penting Horikoshi adalah bahwa ketahanan pendidikan pesantren ada pada kiai yang ternyata tidak hanya memainkan peran sebagai makelar budaya (cultural broker) yang cendrung pasif, tetapi menjadi agen perubahan sosial sehingga baik pesantren maupun masyarakat di sekitarnya tidak mengalami kesenjangan budaya (cultural lag) dengan dunia luar. Meskipun kiai mendorong pesantren dan masyarakat di sekitar pesantren terbuka terhadap dunia luar, pesantren tetap berpijak pada kearifan klasiknya yakni memelihara yang baik dari tradisi lama, dan mengambil lebih baik dari perubahan baru. Dengan demikian, bertahannya pesantren secara implisit mengisyaratkan bahwa tradisi pesantren dari segisegi tertentu masih tetap relevan di tengah arus modernisasi.

Kajian di atas hanya melihat dan menggambarkan ketahanan pesantren terletak pada kepemimpinan kiai dan tradisi pesantren. Sementara dalam kajian ini melihat secara komprehensif ketahanan institusi pendidikan pesantren dengan memakai ilmu sosial sebagai pendekatan dan ini unsur yang kebaruan dalam penelitian ini.

\section{Daya Tahan dan Kontinuitas Pesantren}

Daya tahan dan kontinuitas sistem pendidikan pesantren jika dianalisis dengan teori struktural fungsional ${ }^{54}$ yang digagas oleh Talcott Parsons dengan mengemukakan bahwa agar sistem organisasi sosial dapat bertahan (survive) maka sistem harus memiliki empat hal yang disebut dengan AGIL: ${ }^{55}$ adaptation (adaptasi), yaitu sistem harus menyesuaikan diri dengan lingkungan dan menyesuaikan lingkungan dengan kebutuhan. Goal attainment

${ }^{54}$ Fungsionalisme Struktural adalah salah satu paham atau perspektif di dalam sosiologi yang memandang masyarakat sebagai satu sistem yang terdiri dari bagian-bagian yang saling berhubungan satu sama lain dan bagian yang satu tidak dapat berfungsi tanpa ada hubungan dengan bagian yang lain.

${ }^{55}$ George Ritzer dan Goodman J. Doglas, Teori Sosiologis Modern, terj. Alimadan (Jakarta: Prenada, 2004), h. 121. 
(mempunyai tujuan), yaitu sebuah sistem harus mendefinisikan dan mencapai tujuan utamanya. Integration (integrasi), yaitu sebuah sistem harus mengatur antar hubungan bagian-bagian yang menjadi komponennya. Latency (pemeliharaan pola), yaitu sebuah sistem harus memperlengkapi, memelihara dan memperbaiki, pola-pola kultural yang menciptakan dan menopang motivasi.

Keempat fungsi tersebut, menurut Parsons, berlangsung ke dalam empat sistem tindakan. Pertama, organisasi perilaku yang melaksanakan adaptasi. Kedua, sistem kepribadian, yang melaksanakan pencapaian tujuan. Ketiga, sistem sosial yang menanggulangi fungsi integrasi. Keempat, sistem kultural, yang melaksanakan fungsi pemeliharaan pola. Kelemahan teori yang dibangun Talcott Persons tidak membicarakan tentang kepemimpinan sebuah organisasi, padahal kepemimpinan menjadi kunci melaksanakan program-program di atas dalam struktur organisasi.

Dari teori sturuktur fungsional di atas, dapat dianalisis bahwa sistem pendidikan pesantren mempunyai daya tahan kuat karena sesuai dengan struktur sosial suatu sistem organisasi dalam menghadapi perubahan atau modernisasi. Hal terlihat dalam konsep operasional dalam sistem pendidikan pesantren. Pertama, sistem adaptasi yang dilakukan di pesantren sangat jelas ketika melihat fungsi pesantren yang memosisikan sebagai lembaga pendidikan keagamaan (keislaman) yang tetap menjadi sentral tafaqquh fi al-dîn yang berfungsi memelihara, mengembangkan dan memanfaatkan ilmu-ilmu keislaman. ${ }^{56}$ Bahkan peran nilai antara masyarakat dan pesantren yang diakhiri oleh kemenangan pesantren, sehingga selama masa kolonial pesantren merupakan pendidikan yang banyak beradaptasi dengan rakyat dan tidak berlebihan kiranya untuk menyatakan pesantren sebagai lembaga pendidikan grass root people yang menyatu dengan kehidupan masyarakat.

Adaptasi pesantren dengan lingkungan masyarakat sebagai lembaga pendidikan yang besar dan luas penyebarannya telah banyak memberikan saham dalam pembentukan manusia Indonesia yang religius. ${ }^{57}$ Peranan pesantren dengan berbagai komponennya menjadi bekal dalam proses pembangunan dan perubahan sosial yang menuju tatanan masyarakat berkarakter serta menjadi manusia seutuhnya (insân al-kâmil). ${ }^{58}$ Pesantren mempunyai peran terhadap pengembangan karakter ilmu pengetahuan, baik secara kultur yang dimulai dari konstruksi tentang tradisi kiai, mengaji kitab kuning sampai konstruksi pengetahuan dan amaliah. ${ }^{59}$ Sebagai lembaga peradaban, pesantren sudah saatnya mem-

${ }^{56}$ Atho Mudzhar, "Pesantren Transformatif: Respon Pesantren Terhadap Perubahan Sosial," dalam Edukasi Jurnal Penelitian Pendidikan Agama dan Keagamaan, Jakarta : Puslitbang Depag RI, 2010, h. 13-14.

${ }^{57}$ Lembaga tersebut banyak melahirkan pemimpin bangsa di masa lalu, sekarang dan agaknya juga di masa akan datang. Lulusan pesantren banyak mengambil partisipasi aktif dalam pembangunan bangsa.

${ }^{58}$ Wahid, Menggerakkan Tradisi-tradisi Pesantren, h. 44.

${ }^{59}$ Ahmad Baso, Pesantren Studies 2a: Kosmopolitanisme Peradaban Kaum Santri di Masa Kolonial (Jakarta: Pustaka Afid, 2012), h. 320. 
perhatikan tuntutan ideologi global yang berkembang. Di samping menjalankan fungsi pemeliharaan atau pelestarian nilai-nilai lokal (localities) yang baik, positif dan bermanfaat bagi pesantren juga sudah saatnya mengadaptasinya selama tidak menghancurkan lokalitas. Karena itu, sebagai agen perubahan sosial-ekonomi, pesantren merupakan lembaga pendidikan dari dan untuk masyarakat, atau lembaga berbasis masyarakat, maka pesantren dituntut berpartisipasi aktif dalam perekonomian masyarakat sekitarnya.

Kedua, sistem kepribadian yaitu pencapaian tujuan (goal attainment) pesantren sangat jelas, dalam perspektif historis tujuan pendidikan pesantren pada awal perkembangannya ialah untuk mengembangkan agama Islam, dan lebih memahami ajaran Islam, terutama dalam bidang fikih, bahasa Arab, tafsir, hadis, dan tasawuf. ${ }^{60}$ Sementara itu, tujuan pendidikan pesantren menurut $\mathrm{KH}$. Abdurrahman Wahid adalah terintegrasinya pengetahuan agama dan non agama, sehingga lulusan yang dihasilkan memiliki kepribadian yang utuh dan bulat dalam dirinya tergabung unsur-unsur keimanan dan pengetahuan secara berimbang. ${ }^{61}$

Jika dilihat dari konteks gagasan di atas, tujuan pendidikan pesantren ada dua. Pertama, tujuan khusus yakni mempersiapkan para santri untuk memiliki ilmu agama dan non agama. Kedua, tujuan umum adalah membimbing santri untuk menjadi manusia yang berkepribadian Islam yang mampu mengamalkan ilmunya. ${ }^{62}$ Inilah yang diistilahkan $\mathrm{KH}$. Abdurrahman Wahid sebagai watak hidup mandiri, yang bersumber pada sistem nilai sendiri. ${ }^{63}$ Sistem kepribadian yang dibentuk oleh institusi pesantren adalah menjadi manusia yang melahirkan santri yang memiliki kepribadian Islam dan mampu mengaplikasikan ilmunya serta mempunyai akhlak.

Ketiga, sistem sosial (integration). Dari awal pendidikan pesantren selalu melakukan integrasi seperti pesantren Mabaul Ulum Surakarta, Tebuireng Jombang dan pondok pesantren Gontor, baik secara kelembagaan maupun kurikulum. Bahkan pesantren yang melakukan integrasi mampu menjadi pesantren besar. Perkembangan terakhir, jenis Pesantren Salafiyah telah berkurang diperkirakan tinggal 5.512 pondok pesantren Salafiyah dari 11.211 pondok pesantren yang ada di Indonesia. ${ }^{64}$ Ini berarti lebih dari separuh pondok pesantren di Indonesia telah memodernisasi dirinya dengan mengadopsi sistem klasikal. Pengadopsian sistem klasikal sebagai ciri madrasah memicu pesantren bukan hanya meng-

\footnotetext{
${ }^{60}$ Departemen Agama, Seri Monografi Pondok Pesantren dan Angkatan Kerja (Jakarta: Departemen Agama RI, 2000/2003), h. 12-13.

${ }^{61}$ Abdurrahman Wahid, Bunga Rampai Pesantren: Kumpulan Karya Tulis (Jakarta: Dharma Bhakti, 1984), h. 172-2.

${ }^{62}$ M. Arifin, Kapita Seletakta Pendidikan Islam dan Umum (Jakarta: Bumi Aksara, 2012), h. 248.

${ }^{63}$ Abdurrahman Wahid, Menggerakkan Tradisi-Tradisi Pesantren (Yogyakarta: LKiS, 2010), h. 142.

${ }^{64}$ Husni Rahim, Madrasah dalam Politik Pendidikan di Indonesia (Jakarta: Logos Wacana Ilmu, 2005), h. 76.
} 
adopsi sistem klasikal ansich, tetapi bahkan mengakomodasi lembaga madrasah secara utuh sebagai bagian tidak terpisahkan dari pesantren.

Keempat, sistem pemeliharaan pola (latency). Sistem ini digagas KH. Abdurrahman Wahid dengan istilah teori subkultural pesantren, yang memiliki beberapa aspek: ${ }^{65}$ Aspek kegiatan pesantren berputar pada pembagian periode berdasarkan waktu sembahyang wajib. Kegiatan pokok dipusatkan pada pemberian pengajian buku-buku teks pada setiap habis menjalani sembahyang wajib. Sistem nilai kepesantrenan yang unik dan terpisah dari sistem nilai masyarakat di luarnya. Dalam pesantren terpeliharanya literatur universal selama berabadabad dan diwariskan dari generasi ke generasi. Pola kepemimpinan ${ }^{66}$ yang berdiri sendiri dan berada di luar kepemimpinan pemerintahan desa. Struktur pengajarannya yang unik dan memiliki ciri khas sudah tentu juga menghasilkan pandangan hidup dan aspirasi yang khas pula. Visi untuk mencapai penerimaan di sisi Allah di hari kelak menempati kedudukan terpenting dalam tata nilai di pesantren yang kenal dengan keikhlasan yang mengandung arti ketulusan dalam menerima, memberi dan melakukan sesuatu di antara sesama makhluknya. Sebab itu, pesantren tetap berpegang pada tradisi nilai-nilai dianutnya sehingga dapat berperan sebagai lembaga yang mampu memberikan sumbangan yang berarti dalam membangun sistem nilai dan kerangka moral pada individu dan masyarakat. Seperti sifat kesederhanaan, qanâ'ah, keikhlasan serta etos kerja.

Sistem nilai atau tradisi inilah yang harus dipertahankan dalam sistem pendidikan pesantren dan sepanjang pesantren mempertahankan pranata-pranata atau budaya organisasi yang dimilikinya, maka pesantren bukan hanya sebagai lembaga penyaring kebudayaan, tetapi kemampuan pesantren dalam mengontrol perubahan nilai. Peran inilah yang diharapkan, bukan hanya mampu menjalankan fungsi tradisionalnya, bahkan peran sosial lainnya, seperti menjadi pusat rehabilitasi sosial. Dalam konteks terakhir ini, banyak keluarga yang mengalami kegoncangan atau krisis sosial-keagamaan, lembaga pendidikan pesantren merupakan alternatif untuk menyelamatkan anak-anak bangsa.

Keempat sistem di atas adalah modal pesantren untuk mempunyai daya tahan dan kontiunitas sistem pendidikan. Hanya saja sistem struktur fungsional di atas hanya bisa

${ }^{65}$ Wahid, Bunga Rampai Pesantren, h. 19-42.

${ }^{66}$ Watak sub-kultur yang ditemukan KH. Abdurrahman Wahid dalam nilai, cara hidup, dan model kepemimpinan di atas, pada perjalanannya telah menempatkan pesantren dalam peran ganda: subsistem unik yang terpisah, dan oleh karena itu menjelma alternatif ideal bagi krisis sistemik masyarakat di sekelilingnya. Posisi ideal ini menurutnya sangat sesuai dengan perwujudan kultural Islam yang sampai ke Nusantara. Perwujudan kultural Islam ini mewujud dalam perpaduan antara doktrin formal Islam dengan kultus para wali (berpuncak pada kultus wali songo), sebagai sisa pengaruh pemujaan orang-orang suci (hermits) dalam agama Hindu. Perwujudan kultural tersebut nampak nyata dalam asetisme (al-Zuhûd, kealiman) yang mewarnai kehidupan agama Islam di kepulauan Nusantara, tidak sebagaimana terjadi di negeri-negeri Arab. Di sisi lain, posisi keterpisahan kultural tersebut kemudian dibarengi oleh posisi menjadi bagian dari masyarakat, dalam arti keterlibatan aktif pesantren dalam proses perubahan sosial. Lihat, Abdurrahman Wahid, Bunga Rampai Pesantren, h. 23. 
berjalan jika pesantren memiliki kepemimpinan kiai. Pesantren besar dan bertahan karena peran kiai dalam memelihara budaya organisasi. ${ }^{67}$ Kaitannya dengan kiai sebagai figur sentral di pesantren, kepemimpinan kiai adalah sesuatu yang unik, relasi sosial antara kiai dan santri dilakukan atas dasar kepercayaan, bukan karena patron-klien sebagaimana yang dilakukan masyarakat pada umumnya. Ketaatan santri pada kiai lebih karena mengharapkan barakah misalnya dengan mencium tangan kiai ketika berjabat tangan, mengunjungi rumah kiai, dan meminta doa untuk momen tertentu.

Menurut Horikoshi, kepatuhan para santri dan masyarakat itu disebabkan karena kiai dipandang sebagai orang suci dan dekat dengan Tuhan, ${ }^{68}$ sehingga masyarakat dalam banyak hal mempercayakan penyelesaian permasalahan hidup mereka. Tegasnya, kiai tempat bertanya sumber referensi, tempat menyelesaikan segala urusan, meminta nasehat serta fatwa. Dengan demikian, dapat dipahami bahwa corak kepemimpinan kharismatik tidak dapat dihindari dalam dunia pendidikan pesantren, karena kepemimpinannya diaktori langsung oleh kiai yang mempunyai banyak kelebihan, sehingga pengaruh kiai sangat kuat di pesantren dan masyarakat.

Ketahanan sistem pendidikan pesantren dapat dipahami bahwa pesantren sesuai dengan teori ilmu sosial dalam budaya sebuah organisasi, karena itu pesantren yang besar dan memiliki daya tahan dan kontinuitas adalah pesantren yang melakukan empat sistem fungsi di atas. Jika tidak, maka dapat dipastikan pendidikan pesantren tidak mempunyai daya tahan yang kuat, bahkan akan tergusur sebagai lembaga pendidikan Islam alias menjadi pendidikan umum. Dengan kata lain, meninggalkan salah satu fungsi sistem di atas, maka pendidikan pesantren tidak mempunyai ketahanan, dan mengikuti perkembangan zaman. Inilah yang diistilahkan dalam dunia pesantren yang berbunyi: al-muhâfazhah 'ala alqadîm al-sâlih wa al-akhzu bi al-jadîd al-ashla $\underline{h}$ (memelihara dan melestarikan nilai-nilai lama yang masih positif dan mengambil nilai-nilai baru yang lebih positif).

\section{Penutup}

Kajian ini menemukan bahwa ketahanan sistem pendidikan pesantren dalam perspektif teori struktural fungsionalis mememiliki daya tahan dan kontiunitas yang kuat karena memiliki empat fungsi. Pertama, adaptasi (adaptation) pesantren dengan lingkungan masyarakat. Kedua, mempunyai tujuan (goal atteiment) pesentren membentuk kepribadian santri yang berakhlak. Ketiga, integrasi (integration) pesantren telah melakukan integrasi baik secara sistem kelembagaan maupun kurikulum. Keempat, pemeliharaan pola kultural (latency) sistem nilai di pesantren yang kenal dengan keikhlasan, kemandirian, kesederhanaan, kejujuran, ukhuwah Islâmiyah dan jiwa kebebasan. Bahkan pesantren mempunyai

\footnotetext{
${ }^{67}$ Mardiyah,"Kepemimpinan Kiai dalam Memelihara Budaya Organisasi," h. 27.

${ }^{68}$ Hiroko Horikoshi, Kiai dan Perubahan Sosial (Jakarta: P3M: 1987), h. 232.
} 
kepemimpinan kiai dalam proses pendidikan pesantren. Karena itu, pesantren yang besar dan memiliki daya tahan serta kontiunitas adalah pesantren yang melakukan empat sistem fungsi. Jika tidak, dapat dipastikan pendidikan pesantren tidak mempunyai daya tahan yang kuat, bahkan akan tergusur sebagai lembaga pendidikan Islam.

Sebagai penutup, saran-saran perlu dipertimbangkan. Pertama, penelitian tentang sistem pendidikan pesantren masih sangat minim, karena itu diharapkan para kalangan akademisi untuk memberikan perhatian pada masalah ini secara komprehensif khususnya dengan menggunakan ilmu-ilmu sosial sebagai pendekatan. Kedua, perlunya perhatian dari peneliti untuk pengembangan sistem pendidikan pesantren yang lebih kompetitif, relevan dengan kebutuhan zaman. Ketiga, pesantren dalam mengadopsi sistem pendidikan dari mana pun, tetapi bangunan budaya pesantren harus menjadi indikator dasar dalam melakukan perubahan, sehingga proses pembaharuan akan tetap berada pada tradisinya. Jika tidak, pesantren dapat kehilangan jati diri sebagai institusi pendidikan Islam.

\section{Pustaka Acuan}

Anwar, Ali. "Pembaharuan Pendidikan di Pesantren Lirboyo Kediri." Jakarta: Disertasi UIN Syarif Hidayatullah, 2008.

Arifin, M. Kapita Seletakta Pendidikan Islam dan Umum. Jakarta: Bumi Aksara, 1993.

Azra, Azyumardi. Pendidikan Islam: Tradisi dan Modernisasi Menuju Milenium Baru. Jakarta: Logos Wacana, 2000.

Baso, Ahmad. Pesantren Studies 2a: Kosmopolitanisme Peradaban Kaum Santri di Masa Kolonial. Jakarta: Pustaka Afid, 2012.

Bruinessen, Martin van. Kitab Kuning, Pesantren dan Tarekat:Tradisi-Tradisi Islam di Indonesia. Bandung: Mizan, 1999.

Departemen Agama. Seri Monografi Pondok Pesantren dan Angkatan Kerja. Jakarta: Departemen Agama RI, 2000/2003.

Dhofier, Zamakhsyari. Tradisi Pesantren: Pandangan Hidup Kiai.Jakarta: LP3ES, 2011.

Faturahman, Pupuh. Keunggulan Pendidikan Pesantren: Alternatif Sistem Pendidikan Terpadu Abad XXI. Bandung: Tunas Nusantara, 2000.

Ritzer, George dan Goodman J. Doglas. Teori Sosiologis Modern, terj. Alimadan. Jakarta: Prenada, 2004.

Haedari, Amin. "'Peran Strategis Pesantren, Madrasah dan Sekolah," dalam Jurnal Pondok Pesantren Mihrab," Jurnal Pondok Pesantren Mihrab, vol. II No. 1 Juli 2007.

Hasingsih, Sri. "Peran Strategis Pesantren, Madrasah, dan Sekolah Islam di Indonesia," dalam El-Tarbawi Jurnal Pendidikan Islam, No. 1. Vol. 1. 2008.

Hidayat, Ma'ruf. Kinerja Manajmen dan Proses Pembelajaran pada Pondok Pesantren Ibnul Amin Pamangkih. Darussalam Martapura: 2002. 
MIQOT Vol. XL No. 1 Januari-Juni 2016

Hiroko, Horikoshi. Kiai dan Perubahan Sosial, terj. Umar Baslim dan Andy Muarly Sunrawa. Jakarta: P3M, 1987.

Husaini, Adian. Wajah Peradaban Barat: Dari Hegemoni Kristen ke Dominasi SekularLiberal. Jakarta: Gema Insani, 2005.

Khafidin, Zaenal. "Model Pendidikan Pesantren Madrasah," dalam Jurnal Penelitian, STAIN Kudus, Vol. 2, No. 1, 2008.

Mahduri, M. Annas et al. Pesantren dan Pengembangan Ekonomi Umat: Pesantren al-Ittifaq dalam Perbandingan. Jakarta: Depag RI, 2002.

Madjid, Nurcholish. Bilik-Bilik Pesantren: Sebuah Potret Perjalanan. Jakarta: Paramadina 1997.

Mahfudh, Sahal. Nuansa Fiqih Sosial. Yogjakarta: LKiS, 1994.

Mardiyah. "Kepemimpinan Kiai dalam Memelihara Budaya Organisasi: di Pondok Pesantren Modern Gontor, Lirboyo Kediri, dan Tebuireng Jombang," dalam Jurnal, Vol. 8. No. I. April 2012.

Mastuhu. Dinamika Sistem Pendidikan Pesantren. Jakarta: INIS, 1994.

Mastuhu. Memberdayakan Sistem Pendidikan Islam. Jakarta: Logos Wacana Ilmu, 1999.

Muchlis Solihin, Mohammad. "Modenisasi Pendidikan Pesantren," dalam Jurnal Tarbiyah, Tadris,Vol. 6, No. 1, Juni 2011.

Mudzhar, Atho. "Pesantren Transformatif: Respon Pesantren Terhadap Perubahan Sosial," dalam Edukasi Jurnal Penelitian Pendidikan Agama dan Keagamaan, Jakarta : Puslitbang Depag RI, 2010.

Munawwar Mansur, Fadlil. "Kekayaan Budaya Pesantren," dalam Jurnal Humaniora, Vol. XIV, No. 2/2004.

Nata, Abuddin. Pemikiran Para Tokoh-Tokoh Pendidikan Islam. Jakarta: RajaGrafindo Persada, 2000.

Nata, Abuddin. Kapita Selekta Pendidikan Islam. Bandung: Angkasa, 2003.

Noer, Deliar. Gerakan Modern Islam di Indonesia 1900-1942. Jakarta: LP3ES, 1998.

Putra Daulay, Haidar. Historisitas dan Eksistensi: Pesantren, Sekolah dan Madrasah. Yogyakarta: Tiara Wacana, 2000.

Raehani. "Islam dan Kemajemukan Indonesia: Studi Kasus Pesantren dan Pendidikan Multikultural," dalam Annual Conference on Islamic Studies (ACIS) ke-10, Bajarmasin: 2010 .

Rahardjo, Dawam. "Mozaik Pesantren," dalam Jurnal Modernisasi Manajemen Pendidikan Pesantren". Edisi 02/Tahun I/Nopember 2005.

Husni, Rahim. Madrasah dalam Politik Pendidikan di Indonesia. Jakarta: Logos Wacana Ilmu, 2005.

Steenbrink, Karel A. Pesantren Madrasah Sekolah. Jakarta: LP3ES, 1986. 
Sudibyo, Rahmat Pulung. "Integrasi, Sinergi dan Optimalisasi dalam Rangka Mewujudkan Pondok Pesantren Sebagai Pusat Peradaban Muslim Indonesia". dalam Jurnal Fakultas Pertanian dan Peternakan, Vol. 13, No. 2 Juli-Desember, 2010.

Sumpeno, Ahmad et al. Pembelajaran Pesantren: Suatu Kajian Komparatif. Jakarta: Kemenag RI, 2002.

Suparta, Mundzier. Perubahan Orientasi PondokPesantren Salafiyah, terhadap Prilaku Keagamaan Masyarakat Keagamaan. Jakarta: Asta Buana Sejahtera, 2009.

Supriyono Edy. "Pesantren di Tengah Arus Globalisasi”, dalam M. Affan Hasyim et al. Menggagas Pesantren Masa Depan. Yogyakarta: t.p, 2008.

Zarkasyi, Abdullah Syukri. Gontor dan Pembaharuan Pendidikan Pesantren. Jakarta: Rajawali, 2005.

Tafsir, Ahmad. Ilmu Pendidikan Islam. Bandung: Remaja Rosdakarya, 2012.

Tilaar, H.A.M. Pendidikan Dan Pembangunan Nasional Menyongsong Abad XXI. Jakarta: Balai Pustaka, 1998.

Wahid, Abdurrahman. Menggerakkan Tradisi-Tradisi Pesantren. Yogyakarta: LKiS, 2010.

Wahid, Abdurrahman. Bunga Rampai Pesantren: Kumpulan Karya Tulis. Jakarta: Dharma Bhakti, 1984. 